\title{
Rapid and synchronous ice-dynamic changes in East Greenland
}

\author{
Adrian Luckman, ${ }^{1}$ Tavi Murray, ${ }^{1}$ Remko de Lange, ${ }^{1,2}$ and Edward Hanna ${ }^{3}$ \\ Received 7 December 2005; accepted 22 December 2005; published 3 February 2006.
}

[1] Two major outlet glaciers in East Greenland have suddenly begun to accelerate and retreat. The speeds of Kangerdlugssuaq and Helheim remained steady during the 1990s despite progressive and substantial thinning, but have abruptly increased within the last two years, more than doubling ice flux to the ocean. Had it been an isolated example, the comparable 1998 speed-up of Jakobshavn Isbræ in West Greenland might have been explained simply by its chance retreat past a pinning point. Now that two further Greenland outlets have exhibited similar behavior, a common process seems likely. A remarkable correspondence in the inter-annual patterns of speed and ice-front variation between Kangerdlugssuaq and Helheim implies a significant sensitivity to regional environmental factors. The period of continued warming and thinning appears to have primed these glaciers for a step-change in dynamics not included in current models. We should expect further Greenland outlet glaciers to follow suit. Citation: Luckman, A., T. Murray, R. de Lange, and E. Hanna (2006), Rapid and synchronous ice-dynamic changes in East Greenland, Geophys. Res. Lett., 33, L03503, doi:10.1029/ 2005 GL025428.

\section{Introduction}

[2] Outlet glaciers in Greenland have been thinning over the 1990s [Krabill et al., 2000, 2004; Abdalati et al., 2001] at a rate that cannot easily be explained by changes in surface mass balance. It has been suggested that part of this thinning must result from dynamic change [Thomas et al., 2000, 2003], and indeed two significant outlet glaciers have been observed to have increased in speed in recent years. Jakobshavn Isbræ in West Greenland began a process of thinning, acceleration and retreat in 1998 [Thomas et al., 2003; Joughin et al., 2004; Luckman and Murray, 2005] and Helheim in East Greenland has recently been reported to have accelerated, also in association with a period of substantial thinning [Howat et al., 2005].

[3] Nevertheless, the temporal sparsity of velocity data have made it difficult to explain the nature of the relationships between thinning, acceleration and retreat in these glaciers and Jakobshavn and Helheim remain the only reported observations of significant dynamic change in Greenland despite observed thinning on the majority of measured glaciers. In both of these glaciers the acceleration and retreat has been sudden, despite the progressive nature of warming and thinning over some years. Jakobshavn had

\footnotetext{
${ }^{1}$ Department of Geography, School of the Environment and Society, Swansea University, Swansea, UK.

${ }^{2}$ School of Geography, University of Leeds, Leeds, UK.

${ }^{3}$ Department of Geography, University of Sheffield, Sheffield, UK
}

a floating tongue and the relationship between thinning, acceleration and retreat was complicated by the probable influence of pinning points beneath it [Joughin et al., 2004; Thomas, 2004]. Helheim, and other glaciers in South East Greenland which have been thinning [Krabill et al., 2004], are not believed to have floating tongues [Rignot et al., 2004], but thinning is likely to increase buoyancy near the calving front Howat et al. [2005]. The thinning during the 1990s was especially strong in the South East, with up to $10 \mathrm{~m} \mathrm{yr}^{-1}$ reported for Kangerdlugssuaq [Thomas et al., 2000] and $2 \mathrm{~m} \mathrm{yr}^{-1}$ for Helheim [Abdalati et al., 2001] and subsequent measurements show that this thinning rate has since increased [Krabill et al., 2004].

[4] In this paper, we use satellite radar feature tracking to report on a third significant glacier acceleration and retreat at Kangerdlugssuaq in East Greenland. We examine the recent dynamic and frontal behavior of both Kangerdlugssuaq and Helheim to investigate the nature of the relationship between thinning, acceleration and retreat over the last 13 years.

\section{Methods}

\subsection{Satellite Radar Feature Tracking}

[5] Sufficiently large glacier surface features, such as crevasses, which develop on the glacier tongue and where ice converges further upglacier, form distinct patterns which move with the glacier. The highly consistent imaging geometry and repeat-pass reliability of satellite imaging radar allows these patterns to be tracked, sometimes over considerable distances, by cross-correlation of image patches between repeat-pass pairs of images separated by the full satellite cycle of 35 days [Scambos et al., 1992; Lucchitta et al., 1995; Luckman et al., 2003]. This study uses most of the synthetic aperture radar (SAR) data for the two glaciers archived by ESA from their ERS and Envisat missions from 1992 to present (82 for Kangerdlugssuaq and 60 for Helheim). This does not include the period 20002002 because relevant data were not archived during this period. The ground size of image patches chosen for correlation is $\sim 1 \mathrm{~km}$ square and matches are sought up to $2 \mathrm{~km}$ away in the second of the image pair. Sufficiently robust correlations are accepted on the strength of their signal-to-noise ratio and by comparing the apparent flow direction with that expected in the downslope direction, and the resulting velocity fields are transformed to map coordinates with the use of a digital elevation model. Errors in the technique arise from changes in the crevasse patterns through time and space, geometric transformations of the data, and errors in zero displacement reference points, and are estimated to be less than $\pm 1 \mathrm{md}^{-1}$.

\subsection{Runoff Model}

[6] The monthly runoff model was specially adapted for Greenland studies from the annual runoff degree-day model 

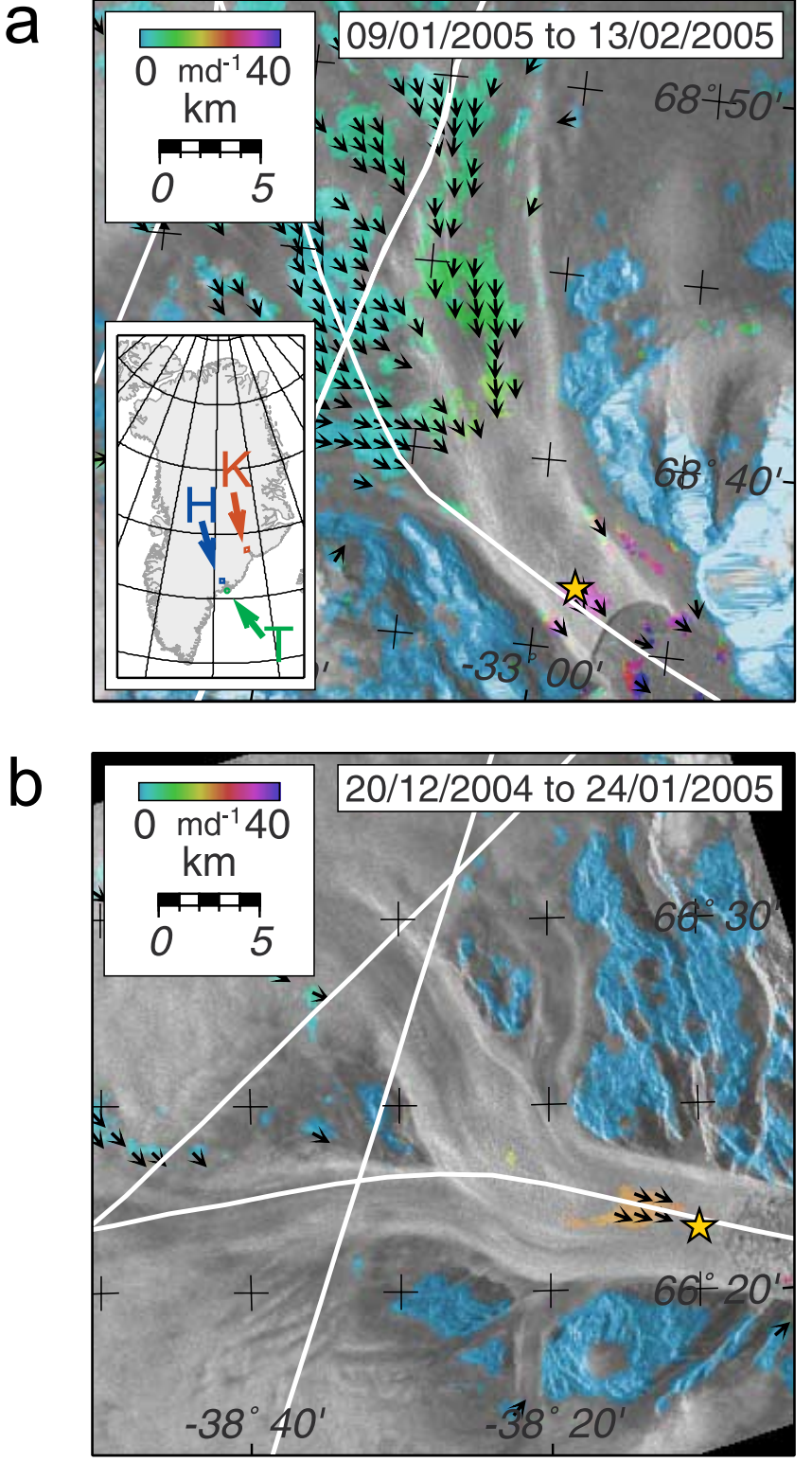

Figure 1. (a) Example Envisat ASAR image of Kangerdlugssuaq ( $\mathrm{K}$ on insert) glaciers in East Greenland overlaid by correlation-based satellite radar feature tracking results showing speeds between the dates given. The feature tracking technique measures the displacement over the 35-day satellite cycle of surface crevasses forming on the glacier tongue and where ice converges further upglacier. White lines show the flight lines of the airborne laser altimeter used to measure thinning rates reported elsewhere, yellow star shows points at which speeds are extracted through time for Figure 2, and green arrow and point indicate location of the Tasiilaq (T) meteorological station. (b) As Figure 1a but for Helheim Glacier (H on insert).

(DDM) of Janssens \& Huybrechts [Hanna et al., 2005; Janssens and Huybrechts, 2000]. It uses the integrated sum of expected positive degree days, and different degree-day factors (DDFs) for snow and ice to calculate surface melt and runoff, and takes into account surface retention [Pfeffer et al., 1991]. The DDM is based on downscaled air surface temperatures from the European Centre for Medium-Range
Weather Forecasting (ECMWF), for which initial errors in ECMWF surface orography and temperature have been corrected using empirically-derived lapse rates and a Greenland digital elevation model [Ekholm, 1996]. The values presented here are the annual sum of monthly values of runoff from the model.

\section{Results}

[7] Examples of the velocity fields from Kangerdlugssuaq and Helheim retrieved by satellite radar feature tracking are shown in Figure 1, along with the location of these glaciers. A representative point was chosen on the glacier tongue at which to measure the temporal variability in speed throughout the sequence of satellite images, in the region of maximum thinning rates reported using airborne laser altimetry along repeat flight-lines [Krabill et al., 2000, 2004; Abdalati et al., 2001] (Figure 1). Around 150 satellite radar images were used to investigate the temporal variation in the flow rates of Kangerdlugssuaq and Helheim from 1992 to 2005 (Figure 2).

[8] The mean annual air temperature at the coastal meteorological station closest to Kangerdlugssuaq and Helheim (Tasiilaq: $65.6^{\circ} \mathrm{N}, 37.6^{\circ} \mathrm{W}$, Figure 2 ) has been generally increasing for the past 15 years, largely as a result of increased winter temperatures. Modelled runoff from these glacier catchments varies considerably during this period (Figure 2) but does not respond directly to temperature at this location because of the influence of associated increasing winter accumulations [Hanna et al., 2005]. Despite the thinning, surface velocities on both glaciers seemed to vary by only around $30 \%$ during this period. Although Kanger-
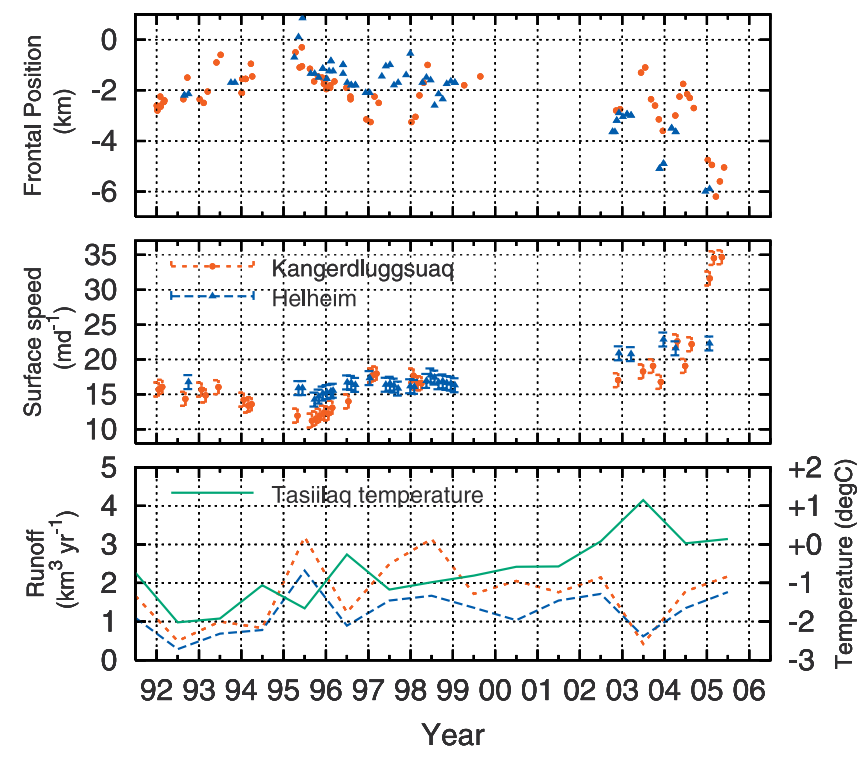

Figure 2. Time series of frontal positions, surface speeds ( $\sim 2 \mathrm{~km}$ from the glacier front), local mean surface air temperature and modelled surface runoff from Kangerdlugssuaq and Helheim glaciers. Note the strikingly similar but modest patterns of advance and retreat, each mirrored by small changes in velocity during the 1990s. Seasonal icefront fluctuations at Kangerdlugssuaq in 2003 and 2004 suggest that the glacier tongue was beginning to go afloat and its speed has doubled within the last 12 months. 
dlugssuaq gradually accelerated between 1996 and 1998, there is no evidence of the very large but brief speed-up predicted by Thomas et al. [2000] in order to explain the observed thinning. Ignoring abrupt frontal changes, which can be controlled seasonally by fjord ice [Sohn et al., 1998], a general reciprocal relationship can be seen at each glacier between ice-front position and speed (Figure 2). Minor retreats of the ice-front accompany speed-ups and modest advances are associated with decelerations. There is a remarkable correspondence in behavior between Kangerdlugssuaq and Helheim during the 1990s: they appear to advance and slow-down, then accelerate and retreat in tandem. This behavior is most pronounced in 1995 and 1996 when a synchronous speed-up and retreat from July 1995 to February 1996 is apparent. The images used to derive the velocities revealing this synchronous variation are acquired from different satellite tracks on different days and are processed independently, removing any possible methodological bias.

[9] The behavior of these glaciers changed markedly between 1999 and 2002 (Figure 2). From April 2004 to April 2005, Kangerdlugssuaq doubled in speed and retreated more than $4 \mathrm{~km}$. From December 2002 to January 2005, Helheim's flow rate increased beyond the 1990s maximum and the calving front retreated an equal distance to Kangerdlugssuaq. Further acceleration and retreat of Helheim have been reported elsewhere [Howat et al., 2005]. During the two years preceding this speed-up, a seasonal oscillation of $\sim 2 \mathrm{~km}$ in frontal position is evident at Kangerdlugssuaq. This sensitivity to the seasonal presence of fjord ice matches closely that seen at the floating tongue of Jakobshavn Isbræ [Sohn et al., 1998; Luckman and Murray, 2005].

\section{Discussion and Conclusions}

[10] The similarity in speed and frontal fluctuations between Kangerdlugssuaq and Helheim, more than $300 \mathrm{~km}$ apart, suggests a previously unobserved sensitivity to some regional environmental forcing, most likely climatic or oceanic in origin. We might expect climate change to have a gradual effect on the speed of Greenland outlets through changes in geometry as current models predict [Huybrechts et al., 2004]. This synchronous behavior, however, demonstrates a more intimate relationship between regional environmental factors and dynamic response. We might expect a relationship to increased ocean temperatures associated with reduced sea-ice extent, or to local air temperature through a greater availability of surface meltwater and potential penetration to the bed [Zwally et al., 2002]. However, despite an upward trend in local air temperature (Figure 2), there is no simple relationship between dynamic response and modelled surface runoff [Hanna et al., 2005].

[11] During the 1990s, the magnitude of the speed and frontal fluctuations of each glacier was modest, despite rising temperatures and significant thinning at lower elevations. Indeed, the discrepancy between flow rate, modelled surface mass balance and apparent thinning at Kangerdlugssuaq remains to be fully resolved [Thomas et al., 2000]. During the 1990s it appears that the dynamics of these two glaciers was hardly perturbed by thinning but was showing sensitivity to some regional climate factor. Since 1999 a threshold has been reached, triggering significant acceleration and retreat, and this seems to have occurred at both glaciers within a relatively short time period. The clear seasonal fluctuation in frontal position immediately preceding the retreat of Kangerdlugssuaq indicates that the glacier tongue became ungrounded [Sohn et al., 1998]. Fewer Envisat images were available for Helheim but similar behavior has been inferred there by investigating the threshold of buoyancy [Howat et al., 2005]. Through immediate changes in basal resistance and longitudinal stresses, ungrounding of the glacier tongue would certainly precipitate abrupt changes in glacier speed in line with tidewater glacier models [Meier and Post, 1987].

[12] We have demonstrated that within the last two years Kangerdlugssuaq and Helheim glaciers in East Greenland have experienced similar accelerations and retreats to that seen at Jakobshavn Isbræ, West Greenland, from 1998. Assuming that the recent thinning is small compared to the calving thickness, the speed-ups at Kangerdlugssuaq and Helheim together approach a doubling of ice flux to the oceans from this part of Greenland from around 50 to $100 \mathrm{~km}^{3} \mathrm{yr}^{-1}$, not including the immediate volume transfer from the disintegrating glacier tongues. The longevity of this flux increase is unknown but could be substantial.

[13] Glacier speeds at Kangerdlugssuaq and Helheim appeared to be robust to the thinning measured during the 1990s but have increased suddenly and near-synchronously. The most plausible sequence of events is that the thinning eventually reached a threshold, ungrounded the glacier tongues and subsequently allowed acceleration, retreat and further thinning. It is reasonable to believe that the 1998 Jakobshavn Isbræ speed-up, also following a long period of stability, was triggered by the same processes of thinning but occurred earlier and after a shorter period of thinning because the tongue was already afloat. Three outlet glaciers behaving in such a way within a few years of each other and after a long period of stability, implies both a common cause and a high probability that other Greenland glaciers will respond likewise. If we are to have confidence in our predictions of the Greenland ice sheet contribution to sealevel rise, then we must better understand and model these non-linear ice dynamic processes.

[14] Acknowledgments. R. de Lange is supported by the UK Engineering and Physical Sciences Research Council. We are very grateful to ESA for the provision of SAR data from both ERS and Envisat satellites through the VECTRA (AO3.108) and Cryosat (AOCRY.2676) opportunities. We thank the ECMWF, British Atmospheric Data Centre and A. Stephens for providing updated meteorological analyses. We are very grateful to David Vaughan of the British Antarctic Survey for helping to improve the manuscript.

\section{References}

Abdalati, W., W. Krabill, E. Frederick, S. Manizade, C. Martin, J. Sonntag, R. Swift, R. Thomas, W. Wright, and J. Yungel (2001), Outlet glacier and margin elevation changes: Near-coastal thinning of the Greenland ice sheet, J. Geophys. Res., 106, 33,729-33,741.

Ekholm, S. (1996), A full coverage, high-resolution, topographic model of Greenland computed from a variety of digital elevation data, J. Geophys. Res., 101(B10), 21,961-21,972.

Hanna, E., P. Huybrechts, I. Janssens, J. Cappelen, K. Steffen, and A. Stephens (2005), Runoff and mass balance of the Greenland ice sheet: 1958-2003, J. Geophys. Res., 110, D13108, doi:10.1029/ 2004JD005641.

Howat, I. M., I. Joughin, S. Tulaczyk, and S. Gogineni (2005), Rapid retreat and acceleration of Helheim Glacier, East Greenland, Geophys. Res. Lett., 32, L22502, doi:10.1029/2005GL024737. 
Huybrechts, P., J. Gregory, I. Janssens, and M. Wild (2004), Modelling Antarctic and Greenland volume changes during the 20th and 21st centuries forced by GCM time slice integrations, Global Planet. Change, $42(1-4), 83-105$.

Janssens, I., and P. Huybrechts (2000), The treatment of meltwater retention in mass-balance parameterizations of the Greenland ice sheet, Ann. Glaciol., 31, 133-140.

Joughin, I., W. Abdalati, and M. Fahnestock (2004), Large fluctuations in speed on Greenland's Jakobshavn Isbræ glacier, Nature, 432(7017), $608-610$.

Krabill, W., W. Abdalati, E. Frederick, S. Manizade, C. Martin, J. Sonntag, R. Swift, R. Thomas, W. Wright, and J. Yungel (2000), Greenland ice sheet: High-elevation balance and peripheral thinning, Science, 289, $428-430$.

Krabill, W., et al. (2004), Greenland Ice Sheet: Increased coastal thinning, Geophys. Res. Lett., 31, L24402, doi:10.1029/2004GL021533.

Lucchitta, B. K., C. E. Rosanova, and K. F. Mullins (1995), Velocities of Pine Island glacier, West Antarctica, from ERS-1 SAR images, Ann. Glaciol., 21, 277-283.

Luckman, A., and T. Murray (2005), Seasonal variation in velocity before retreat of Jakobshavn Isbræ, Greenland, Geophys. Res. Lett., 32, L08501, doi:10.1029/2005GL022519.

Luckman, A., T. Murray, H. Jiskoot, H. D. Pritchard, and T. Strozzi (2003), Automatic ERS SAR feature-tracking measurement of outlet glacier velocities on a regional scale in East Greenland, Ann. Glaciol., 36, 129134.

Meier, M. F., and A. Post (1987), Fast tidewater glaciers, J. Geophys. Res., 92, 9051-9058.

Pfeffer, W. T., M. F. Meier, and T. H. Illangasekare (1991), Retention of Greenland runoff by refreezing: Implications for projected future sealevel change, J. Geophys. Res., 96(C12), 22,117-22,124.
Rignot, E., D. Braaten, S. P. Gogineni, W. B. Krabill, and J. R. McConnell (2004), Rapid ice discharge from southeast Greenland glaciers, Geophys. Res. Lett., 31, L10401, doi:10.1029/2004GL019474.

Scambos, T. A., M. J. Dutkiewicz, J. C. Wilson, and R. A. Bindschadler (1992), Application of image cross-correlation to the measurement of glacier velocity using satellite image data, Remote Sens. Environ., 42, $177-186$.

Sohn, H.-G., K. C. Jezek, and C. J. van der Veen (1998), Jakobshavns Glacier, West Greenland: 30 years of spaceborne observations, Geophys. Res. Lett., 25(14), 2699-2702.

Thomas, R. H. (2004), Force-perturbation analysis of recent thinning and acceleration of Jakobshavn Isbrae, Greenland, J. Glaciol., 50(168), $57-$ 66.

Thomas, R. H., W. Abdalati, T. L. Akins, B. M. Csatho, E. B. Frederick, S. P. Gogineni, W. B. Krabill, S. S. Manizade, and E. J. Rignot (2000), Substantial thinning of a major east Greenland outlet glacier, Geophys. Res. Lett., 27, 1291-1294.

Thomas, R. H., W. Abdalati, E. Frederick, W. B. Krabill, S. Manizade, and K. Steffen (2003), Investigation of surface melting and dynamic thinning on Jakobshavn Isbrae, Greenland, J. Glaciol., 49, 231-239.

Zwally, H. J., W. Abdalati, T. Herring, K. Larson, J. Saba, and K. Steffen (2002), Surface melt-induced acceleration of Greenland ice-sheet flow, Science, 297, 218-222.

R. de Lange, A. Luckman, and T. Murray, Department of Geography, School of the Environment and Society, Swansea University, Swansea SA2 8PP, UK. (a.luckman@swansea.ac.uk)

E. Hanna, Department of Geography, University of Sheffield, Sheffield S10 2TN, UK. 